\title{
La metáfora en la obra de Julio Herrera y Reissig
}

Dedico este ensayo a mi maestro Enrique Anderson Imbert, a quien debo mi orientación critica.

$\mathbf{J}^{\mathrm{n}}$

ULIo Herrera y Reissig es uno de los poetas modernistas menos estudiados; por lo menos, en lo que respecta al elemento primordial de su creación poética: la metáfora. Sin embargo, es precisamente su prodigiosa riqueza metafórica lo que le asegura un lugar de distinción entre sus contemporáneos. Nos proponemos describir algunos de los procedimientos más imaginativos de esta poesía, caracterizada sobre todo por su desiumbrante potencia verbal, en la cual surge la metáfora ya no como medio sino como fin de la expresión poética.

La metáfora es visión, original visión de esencias. No es un adorno - como la definía la vieja retórica- sino un modo de intuir la realidad. Nuestra lógica clasifica los objetos en categorías distintas; pero nuestra fantasía, mediante la metáfora, los confunde líricamente. Gracias a la metáfora, pues, nos acercamos a la expresión de lo inefable. En la síntesis metafórica las palabras suelen descargarse de sus contenidos lógicos tradicionales y adquieren en cambio un nuevo valor de intimidad.

Todo lenguaje es metafórico, puesto que al hablar constantemente estamos incluyendo en las palabras nuevos contenidos de significación. Las palabras, después de todo, son meras abstracciones de nuestra concreta, rica y colorida experiencia personal, y no pode- 
mos evitar que nuestra fantasía, voluntad, sentimiento y modo de vivir, se deslicen aun dentro de los símbolos más lógicos y los conviertan en imágenes íntimas. Pero si bien todo lenguaje es metafórico, al estudiar las metáforas de un poeta debemos tener en cuenta sólo ésas que revelan la intención de hacer valer, estéticamente, la síntesis imaginativa de objetos que, desde el punto de vista de la lógica común, suelen considerarse diferentes. Alguna vez fué metafórico llamar "luciérnaga" al insecto que de noche ểmite luz, pero hoy esa palabra corre por el río de la lengua, como metáfora muerta. "Luciérnagas de oro" es ya una metáfora, aunque debilitada por el uso. En cambio los versos:

Luciérnagas de oro, llevando en sus arcas tesoros que hoy sólo se dan en Ormuz, temblando escribían, para las estrellas, en hojas de rosas, mensajes de luz,

(El hada manzana)

muestran la voluntad de Herrera y Reissig de imponer al lector la conciencia de nuevas notas en el objeto "luciérnagas". Sólo a este tipo de metáforas enérgicas, excitantes de la fantasía, sorprendentes por la percepción original que las ha originado, nos referiremos en nuestro estudio.

Un rasgo impresionista de la poesía de Herrera y Reissig es el uso frecuente de toda clase de metáforas personificadoras, por medio de las cuales da vida corpórea a las cosas inanimadas o abstractas. En virtud de esta tendencia logra fortalecer su propia mira, su visión personal de la realidad que le circunda. Con esta técnica, estructura poemas enteros a base de personificaciones. El monasterio, por ejemplo:

Descalzo en dura arcilla, con el sayal escueto,

la cintura humillada por borlones de hiedra...

viene a concretarse en persona imaginada por el artista :

Inmóvil ermitaño sin gesto y sin palabras, en su cabeza anidan cuervos y golondrinas,

(El monasterio) 
Asimismo líricamente surge vivificado el burgo:

Rige chillonamente gitana vestimenta:

chales de siembra, rosas, y una carga opulenta

de ágatas, lapislázulis y collares de viña.

(El burgo)

Se observan en muchas de sus composiciones distintos procedimientos de personificación metafórica: a menudo lo inanimado realiza acciones humanas.

Agonizando las postreras lilas

me hablaron de las cintas de tu moño

y el húmedo crepúsculo de otoño

pensaba en la orfandad de tus pupilas.

(Amor blanco)

La noche en la montaña mira con ojos viudos

de cierva sin amparo que vela ante su cría;

y como si asumieran un don de profecia,

en un sueño inspirado hablan los campos rudos.

( $L a$ noche)

Es característico que estas actividades giren en torno de la montaña :

y el cielo campesino contempla ingenuamente

la arruga pensativa que tiene la montaña.

(El almuerzo)

y la pradera huraña mira, en éxtasis verde,

al monte que en el cielo enfosca un gesto oscuro.

(Claroscuro)

La visión poética de Herrera y Reissig insufla vida anímica a la materia :

El alma de las montañas,

de sugestiones tranquilas.

(La muerte del pastor)

El lago azul de sueño, que ni una sombra empaña,

es como la conciencia pura de la montaña...

(La noche)

E1 lector encuentra conceptos animalizados:

$Y$ su piedad humilde lame como una vaca.

(El cura) 
de un orgullo que gruñe como un perro a la puerta.

$$
\text { (la huetta) }
$$

Y soslaya sus ojos de mastín bravo y noble

el orgullo que roe la tristeza cantabra

$$
\text { (El mayoral) }
$$

y las abstracciones están dotadas de poderes humanos:

¡En el clorótico espanto de la vela sibilina,

tus ausencias meditaban en mi gran desolación!

(La ausencia meditativa)

La inocencia del día se lava en la fontana.

(El despertar)

Atribuye el poeta vida espiritual a los fenómenos absolutos:

Oscurece. Una mítica Majestad unge el dedo pensativo en los labios de la noche sin miedo.

\section{(La huerta)}

Con mira más directa, la naturaleza queda vinculada a una persona campesina:

y la montaña luce, al tardo sol de invierno, como una vieja aldeana, su delantal de lino

$$
\text { (El regreso) }
$$

o con la misma técnica evoca una escena rural :

Y el monte, que una eterna candidez atesora, rie como un abuelo a la joven mañana, con los mil y mil pliegues de su cara pastora.

$$
\text { (Los perros) }
$$

A veces la personificación va en busca de la sensación rara:

$$
\begin{aligned}
& \text { ríen los labios de leche } \\
& \text { de los luceros precoces; }
\end{aligned}
$$

$$
\text { (El laurel rosa) }
$$

y como producto de su evocación única de un paisaje soñado, envuelto en velo lírico, el recurso se hace más dinámico en los versos que siguen:

Llovió. Trisca a lo lejos un sol convaleciente, haciendo entre las piedras brotar una alimaña 
y al son de los compactos resuellos del torrente con áspera sonrisa palpita la campaña ...

(El almuerzo)

Este constante recurso de personificación en la lírica del poeta uruguayo tiende a reforzar la proyección espiritual sobre la materia inerte. A veces este procedimiento de animación parece trabajar en dirección inversa ya que despersonaliza lo que tiene personalidad. El poeta, pues, en un momento de tensión imaginativa, gusta imaginarse a seres humanos en su tránsito a lo inerte:

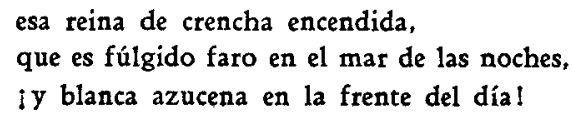

(Plenilunio)

y finalmente en bellísima imagen se sintetizan varios procedimientos personificadores:

Volaron las aves cual almas de flores, y serpentinearon las magas Auroras,

(El hada manzana)

En la poesía de Herrera y Reissig, que se caracteriza por el refinamiento de los sentidos, al lado de las percepciones ópticas, insiste en las sonoras. Vemos y oímos el mar en una misma imagen:

$$
\begin{aligned}
& \text { E1 mar, como gran anciano, } \\
& \text { lleno de arrugas y canas, } \\
& \text { junto a las playas lejanas } \\
& \text { tiene rezongos de anciano. }
\end{aligned}
$$

(Desolación absurda)

Este mismo elemento acústico implícito en la palabra "rezongo" se repite a lo largo de su poesía:

los frailes rezongan Patres y rosarios,

(El canto de los meses)

Huraño el bosque muge su rezongo,

(Neurastenia)

Un rezongo de abejas beatifica y solaza ...

(El domingo) 
Este afắn de captar sonoridades $\mathrm{y}$, al mismo tiempo, de darles sentido dentro de la estructura del poema, lo lleva a un insistente uso de onomatopeyas: zumbido de avispas y de moscas, voces del camino, etc.

$\ldots Y$ en los torvos carrizales zumbaba con dulzuras patriarcales el cuerno de los últimos pastores.

(Luna de miel)

Y zumba la leyenda ecuestre de la caza en medio de un hierático crepúsculo del Norte.

(Otoño)

En su poesía de vena más desequilibrada y retorcida se nota la misma insistencia de esta invasión de su intimidad:

zumbando el scherzo inmenso de un orquestrión astronómico

$$
\text { (La vida) }
$$

hasta culminar en esta percepción extra-terrenal:

Del insonoro interior de mis oscuros naufragios. zumba, viva de presagios,

la Babilonia interior.

(La Totre de las Esfinges)

Junto con el verbo "zumbar", muchas son las onomatopeyas de uso corriente que se repiten a lo largo de su poesía:

Todo duerme. A intervalos lastiman en la noche los aullidos del perro que vela ante la tumba.

(El entierro)

Y estimula el buen ocio un trin-trin de campana, un pum-pum de timbales y un fron-fron de vibuelas.

\section{(La misa cándida)}

Esta voluntad de convertir los sonidos que percibe, en palabras significantes, lo lleva a inventar onomatopeyas. Asi Herrera y Reissig no aprovecha, pasivamente, de los recursos normales, establecidos por la lengua, para referirse a un objeto con palabras que ya en su sonido evocan ese objeto, sino que, activamente, oye y con lo que 
oye crea un símbolo sonoro-lógico. Veamos algunos ejemplos de estos neologismos onomatopéyicos:

por donde un coche antiguo, de tintinante mula, llena de retornelos la tarde placentera.

(Idilio)

pasan silbidos lentos $y$ aires de tiempo ambiguo, en tintinabulantes carros madrugadores.

(Los carros)

cien mil grillos cric-craquean

su nocturno monocorde;

(El laurel rosa)

... Un grillo cri-crea entre la ventana ...

(Canícula)

y al son del gluglutante rezongo de la olla.

(Meridiano durmiente)

Además logra dar un efecto sonoro por la repetición de ciertas letras:

$$
\begin{aligned}
& \text { Canta la noche salvaje } \\
& \text { sus ventriloquias de Congo, } \\
& \text { en un gangoso diptongo } \\
& \text { de guturación salvaje... } \\
& \text { ( La Torre de las Esfinges) } \\
& \text { se raja la carcajada } \\
& \text { estridente de Plutón! ... } \\
& \text { (La Torre de las Esfinges) }
\end{aligned}
$$

De paso notamos que en una composición, Recepción instrumental del gran poligloto Orfeo, escrita bajo la manifiesta influencia de Rubén Dario, se tonaliza la idea en una serie de imágenes adecuadas a los varios instrumentos que se describen.

Alcanzando un valor lírico de primer orden, puesto que llegan a reflejar un puro estado de alma del poeta, percepciones olfativas logran superar en muchos casos a las sonoras. Dos muestras bastarán para que el lector se sienta invadido por marejadas de aroma; en un caso de aroma de cosas reales; en otro, de aroma ideal:

Todo fué así: sahumábase de lilas

$y$ de heliotropo el viento en tu ventana;

( $E l$ enojo) 


\section{Para mis penas fueran divina magia hipnótica sus labios incensarios de místicos sahumerios;}

(Las atañas del augurio)

De las imágenes trabajadas por un solo sentido pasemos ahora a las metáforas sinestésicas en las que diversos estímulos sensoriales se funden en una armónica unidad. Acaso en esta fina expresión de la totalidad vibrante de su vida espiritual es donde Herrera y Reissig ha conseguido un lirismo más hondo, de visión sintética. De mayor frecuencia en su poesía son las imágenes en que se funden color y sonido:

$$
\begin{gathered}
\text {.. Mil notas auroran } \\
\text { el aire de ruidos, mil notas confusas. } \\
\text { (Recepción instrumental del gran } \\
\text { poligloto Otfeo) }
\end{gathered}
$$

Cantando la tartamuda frase de oro de una flauta.

(Desolación absurda)

Ardió el epitalamio de tu paso un himno de trompetas fulgurantes.

$$
\text { (Epitalamio ancestral) }
$$

fijan cromáticos ayes

las Sirenas $y$ en acordes trampolines de agua viva ruedan Nereidas de ónices;

(El laurel rosa)

y del mismo tipo esta imagen espléndida:

En el ritual de las metempsicosis, bramaron fulgurantes apoteosis los clarines del Sol...

(Oleo indostánico)

También a la percepción óptica y acústica logra añadir el gusto:

Una música absurda y poseída con cárdeno sabor de sepultura, dislocó de macabra y de otra vida, el daño de mi enferma conjetura... 
En otra forma de sinestesia se une con el gusto el sentido olfativo:

una fragancia salobre
denuncia el baño de Venus
en el ámbar de su cofre...

(El laurel rosa)

y tímidamente se cruza el tacto, con percepciones sonoras y ópticas, en metáfora de extraordinaria belleza:

temblaron del cosmos los ígneos andamios,

y en sus húmedas lenguas sonoras

cantaron los ríos sus epitalamios.

(El hada manzana)

Pero el ayuntamiento de diversos sentidos en la poesía de Herrera y Reissig culmina en estos versos que representan su hallazgo más sintético de metáfora de esta clase:

Ríe estridentes glaucos el valle; el cielo franca risa de azul; la aurora ríe su risa fresa;

y en la era en que ríen granos de oro y turquesa exulta con cromático relincho una potranca...

(La casa de la montaña)

Toda metáfora es dinámica, puesto que expresa enérgicos movimientos de la fantasía. Herrera y Reissig logra reforzar esa calidad dinámica, no sólo por la fuerza con que incluye percepciones sorprendentes en el lenguaje normal, sino también porque muchas veces prefiere metaforizar con los temas del movimiento mismo. Parecería que para él el universo estuviera siempre en acción, siempre mostrándose en gestos. De aquí que los verbos sean a menudo portadores de metáforas.

Con metáfora exquisita consigue representar estéticamente el instante en que un fenómeno de la naturaleza, ya personificado, irrumpe para convertirse en movimiento, cuando sale del sueño nocturno:

... La joven brisa se despereza...

(El alba)

En situación análoga se acentúa el paso de la noche al día:

Y hacia la aurora sesgan agudas golondrinas como flechas perdidas de la noche en detrota.

(El despertar) 
Todo es movimiento en su evocación espiritualizada del campo:

Tirita entre algodones húmedos la arboleda

La cumbre está en un blanco éxtasis idealista;

$y$ en bruscos sobresaltos, como ante una imprevista

emboscada, el torrente relinchando rueda.

(La flauta)

y en lácteas vibraciones de ópalo, gesticula

allá, bajo una encina, la mancha de una hoguera

(Idilio)

y cuando se cristaliza la composición en su yo concreto, escribe:

su clara risa entre sus labios rojos

triscaba como un chorro de agua viva.

(Primavera)

Al asomarse al mundo, se deja encantar por espectáculos de violencia :

Un estremecimiento de Sibilas epilepsiaba a ratos la ventana,

(Alba triste)

En toda una serie de metáforas insólitas, Herrera y Reissig suprime las leyes lógicas que rigen la materia y ésta adquiere el temple lírico del poeta. En esta desrealización quita materialidad a las cosas; se sumergen aún más en el mundo fantástico del poeta $\mathrm{y}$, al desplegar el abanico de su tremendo poder imaginativo, $\mathrm{He}-$ rrera y Reissig nos invita a contemplar una realidad a veces en el proceso de transformarse, que se esfuma líricamente, para salir un momento después refrescada bajo el pincel mágico del poeta e interpretada por su imaginación deslumbrante. La poesía ya no está en la cosa misma, sino más bien en su íntima manera de enfocarla y de empaparla con el hálito de su propia sensibilidad.

En su visión más conturbada y extravagante, esta desrealización se vislumbra en la extrema tensión de la subconciencia:

Ante el augurio lunático, capciosa, espectral, desnuda, aterciopelada $\mathrm{y}$ muda, desciende en su tela inerte, 
como una araña de muerte,

la inmensa noche de Buda...

(La Totre de las Esfinges)

De la misma composición irracional e incoherente entresacamos los siguientes versos desligados del fenómeno real:

y se suicida, en la extraña

vía láctea, el meteoro,

como un carbunclo de oro

en una tela de araña.

(La Torre de las Esfinges)

$\mathrm{Y}$ el nexo lógico se pulveriza en esta visión:

habla el Silencio; palpita

la inmensa Nada sin nombre;

brama la Esfinge el enigma

de sus vigilias inmóviles;

(La Torre de las Esfinges)

No obstante, cuando se remansa el torrente verbal, en sus poesías de inspiración más clara y equilibrada, se transfigura la naturaleza en una irrealidad de ensueño. Término medio entre la personificación y la desrealización lírica sería la estrofa que citamos abajo:

Todo es grave . . En las cañas sopla el viento flautista.

Mas súbito, rompiendo la invernal humareda,

el sol, tras de los montes, abre un telón de seda,

y ríe la mañana de mirada amatista.

$$
\text { (La flauta) }
$$

Con una mira subjetivizada en extremo recrea la siguiente escena:

Con sus densos perfiles y sus abruptos conos, a lo lejos, la abstracta serrania concreta una como dormida tormenta violeta que el crepúsculo prisma de enigmáticos tonos.

(Bostezo de luz)

Luego el poeta, como lo hace a menudo, parte de un suceso cotidiano, para que en los dos últimos versos de la estrofa surja la visión, completada por el toque irreal de su propia fantasía: 
Sueña, de roca en roca, sus cándidos trintrines la vagabunda esquila del rebaño, y en coro, ante Dios que retumba en la tarde, urna de oro, los charcos panteístas entonan sus maitines.

(Las madres)

Un momento contemplativo del poeta se describe así:

Un billón de luciérnagas de fina esmeralda rayaba la pradera.

Bajo un aire fugaz de muselina, todo se idealizaba, cual si fuera el vago panorama, la divina materialización de una quimera...

(Nirvana crepuscular)

De esta suerte, abandonando por el momento la perfecta idealización lírica de la cita anterior, al par que desrealiza la naturaleza, se destaca el poeta en la metáfora que acierta a captar lo instantáneo, el matiz transitorio. Nos sugiere los momentos fluctuantes de los caminos:

Lilas, violetas, lóbregas, mudables como ojeras,

las rutas, poco a poco, apatecen distintas;

(Las horas graves)

y en imagen estupenda pasa un tren fugitivo:

manchó la soñadora transparencia

de la tarde infinita el tren lejano,

aullando de dolor hacia la ausencia.

(La sombra dolorosa)

Asimismo se evoca un instante del ocaso:

La tarde en la montaña, moribunda se inclina,

y el sol un postrer lampo, como una aguja fina,

pasa por los quiméricos miradores de encaje

(El teatro de los humildes)

y la inspiración erótica se acentúa en la fugacidad de un instante en que

iY un astro fugitivo, aquel momento, segó de plano a plano el Infinito, 
como si el mismo Dios hubiera escrito su firma sobre auestro juramento!...

(El juramento)

Por último acierta a sorprender la intimidad del paisaje nocturno:

Rayan el panorama, como espectros agudos. tres álamos en éxtasis... Un gallo desvaría, reloj de media noche. La grave luna amplía las cosas, que se llenan de encantamientos mudos.

(La noche)

Algunos de los hallazgos metafóricos más felices de Herrera y Reissig, parecen armarse alrededor de ciertos motivos temáticos en los cuales insiste el poeta. Estos temas predilectoș, si pueden en realidad llamarse temas, adquieren vida $\tan$ independiente que son metáforas en sí. Las ojeras, por ejemplo, aparecen y desaparecen en la poesía de Herrera y Reissig con tal reiteración que ya no importa lo que signifiquen: su sola presencia incluye una nota de fantasía y así, con su inclusión, todo se hace metáfora. Estos motivos no son símbolos -en el sentido en que podría llamarse símbolo al motivo del cisne en Rubén Darío-; no tienen intención intelectual, no substituyen ninguna idea; son, puramente, dilectos puntos de apoyo que el poeta busca en la realidad, para subir sobre ellos. El poeta quisiera darle a su fantasía un vuelo libre; pero, obligado a pisar siempre en las cosas, elige ésas que dan fuerza ascencional a su imaginación: "ojera", "molino" "algodón", etc.

$$
\begin{aligned}
& \text {.. iY en las riberas } \\
& \text { echóse a descansar, meditabunda, } \\
& \text { la caravana azul de tus ojeras!... } \\
& \quad \text { (El crepúsculo del martitio) } \\
& \text { Da nostalgias de Cartujas } \\
& \text { el ciprés de terciopelo, } \\
& \text { y vuelan de tu pañuelo, } \\
& \text { en fragantes confidencias, } \\
& \text { interjecciones de ausencias } \\
& \text { y ojeras de retornelo. } \\
& \text { (La Torre de las Esfinges) }
\end{aligned}
$$

$Y$ arden en un halo espectral de heliotropo sus clementes ojeras otoñales de luna. 
y vuelan sus ojeras otoñales de bruma, como vagas libélulas de una tarde heliotropo.

(Berceuse blanca)

Otra serie de metáforas se motiva en el molino:

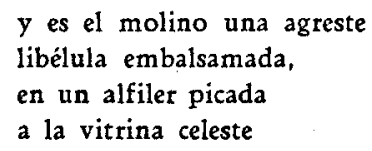

(La Totre de las Esfinges)

y sigue proyectándose hacia arriba, al mismo tiempo que configura la realidad:

rasga un grillo el silencio perfumado de rosas...

El molino en el fondo, abrazando la luna,

inspira de romántico viejo tiempo las cosas.

(El teatro de los humildes)

Y a modo de espectrales obsesiones,

la torva cornamenta de un molino

amenazaba las constelaciones...

(Idealidad exótica)

Por último, llega el momento en que el molino no sólo es punto de partida para que vuele la imaginación del poeta, sino que metaforiza por su propia cuenta:

Adarga en ristre, el sonámbulo

molino metaforiza

un Don Quijote en la liza, encabalgado y sonámbulo...

(La Totre de las Esfinges)

Repetidas veces el Hada Neblina, relacionándose con el algodón, da origen a visiones metafóricas:

Flora, enferma, se desmaya mientras el Hada Neblina abre a los silfos del sueño su palacio de algodón.

$$
\text { (Esplin) }
$$

Fué mi llanto a la ribera. Mientras el hada Neblina abdicó frívolamente su corona de algodón...

( $L a$ ausencia meditativa) 
y en busca de la sensación rara y decadente, leemos:

crucificame en tus brazos, mientras el Hada neblina fuma el opio neurasténico de su cigarro glacial.

(Esplín)

Desde edades remotas, el poeta ha buscado su inspiración lírica en la luna; pero Herrera y Reissig saca a luz el viejo tema para pulirlo con brillos nuevos. Ya no es la luna quieta de los románticos:

$\mathrm{y}$ con aire acrobatil, bajo la inquieta laguna, hace piruetas la luna, sobre una red de marfil.

(Desolación absurda)

Más convencionalmente se convierte en agente hipnótico:

El invierno embalsama con sugestión de faustos emolientes las cosas... Ebria por el ventisco

la luna sesga en póstuma decrepitud su disco de azogue que hipnotiza los predios inexhaustos.

(Invierno)

La luna hipnotizaba nimbos vivos, surgiendo entre abismáticos espejos.

(Panteismo)

De muchos otros ejemplos hemos escogido éste de visión muy personal que vuelve a indicar la recreación artística tan característica del poeta:

Los astros tienen las mejillas tiernas...

La Luna trunca es una paradoja espectro-humana. Prosperina arroja su sangre al mar. Las horas son eternas.

(Génesis)

Muchas son las notas insistentes en la poesía de Herrera y Reissig. Me permito dar otra muestra: el tema de las manos y el piano:

¡Oh, si pudiese hallarla! Soñaba en este día que ilusionó el palacio de mi melancolía: sus finas manos ebrias de delirar armónicas dulzuras de los parques, vagaban en el piano 
sonambuleando, y eran las blancas filarmónicas arañas augurales de un mundo sobrehumano.

(Las arañas del augurio)

Hemos insistido en el hecho de que Herrera y Reissig infunde un estremecimiento lírico en todo lo que ve; llega así el momento arrebatado en que su yo se funde con las cosas. El mismo nos da la clave de su propia mira, cuando escribe:

Ella ve una imploración por la salud de sus males en la devota humildad de los sauces fraternales.

Un espejo la objetiva. Todo lo que ella ha sentido lo contempla en el paisaje, transmigrado y confundido

(Ciles alucinada)

y en otro poema leemos la siguiente confesión:

$$
\begin{aligned}
& \text { Las cosas se hacen facsimiles } \\
& \text { de mis alucinaciones } \\
& \text { y son como asociaciones } \\
& \text { simbólicas de facsimiles... } \\
& \text { ( } L a \text { Torre de las Esfinges) }
\end{aligned}
$$

Con este punto de partida, la fusión del yo intimo del poeta con la realidad exterior alcanza su más alto valor metafórico, hasta darnos una perfecta sintesis:

$$
\begin{aligned}
& \text { Es la divina hora azul } \\
& \text { en que cruza el meteoro, } \\
& \text { como metáfora de oro } \\
& \text { por un gran cerebro azul. } \\
& \text { (Desolación absurda) }
\end{aligned}
$$

En imagen no menos espléndida, en otro lugar escribe el poeta:

Cual murciélagos inmensos los nubarrones se acercan y en sus pupilas oscuras hay relámpagos de espanto. ¡A Abre pronto mi ventana, míralos como me cercan con sus alas empapadas en la lluvia de mi llanto!

(Holocausto)

El ser consciente de este Yo-Mundo, a veces desliza dentro de sus metáforas un hilo lógico, un pensamiento no ya intuitivo sino conceptual: entonces la metáfora se le hace alegoría. $\mathrm{El}$ poeta medi- 
ta sobre lo que percibe y nos dice, mientras junto al mar escucha los rugidos de las encrespadas olas:

¡Oye, ese ruido es el saldo de mis esperanzas rotas;

las olas son mis ideas; la tempestad soy yo mismo!

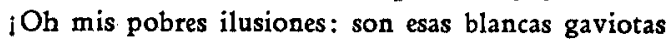

que hacen el nido en las peñas y se lo traga el abismo!

(Holocausto)

La tarde se convierte en amante:

Junto a los surtidores, la presencia semidormida de la tarde de oro, decíate lo mucho que te adoro y como era de sorda mi dolencia.

(El camino de las lágrimas)

$\mathrm{Y}$ luego, en otro momento erótico, la realidad entra en el alma del poeta y su amada:

Luego: la inmensidad, el astro, el hondo

silencio, todo penetró hasta el fondo

de nuestro ser... Un inaudito halago

de consubstanciación y aéreo giro

electrizónos, y hacia el éter vago

subimos en la gloria de un suspiro...

(Panteismo)

Sin propósito de agotar las posibilidades de un estudio sobre la metáfora en Julio Herrera y Reissig, en las páginas anteriores hemos procurado tan sólo trazar a grandes rasgos algunos de sus más visibles procedimientos imaginativos. Sería injusto pretender que pueda reducirse a un mero artículo nada menos que el rasgo esencial de toda su lírica. De esta magnífica creación de insólitas imágenes no hemos tocado más que algunas facetas de su asombrosa capacidad de ver metafóricamente la realidad que le rodea. En cuanto a los muchos recursos metafóricos que quedan por ver - los cuales debiera tratar un estudio más amplio que éste-, sólo mencionemos la metáfora de antítesis, no muy frecuente ni muy feliz en su poesía; otras metáforas de tipo alegórico en las cuales se viste un concepto interior, que es su núcleo, con el externo ropaje imaginativo propio de la visión metafórica, y, por último, todo un grupo de imágenes, armadas con fin de captar la sensación rara, 
exquisita; una tendencia que se vislumbra, como se habrá observado, en muchos de los ejemplos ya citados en nuestra exposición del tema.

En virtud de nuestro estudio de la metáfora en Julio Herrera y Reissig, creemos que la esencia de su manera espiritual de concebir la realidad corresponde a un constante flujo y reflujo, en oleajes de emoción, entre él y las cosas. Procedente de este intercambio emocional entre el poeta y la realidad contemplada, brota la visión lírica de nuestro artista. En su poesía, que obra por sugestiones evocadoras, la idea se esfuma en pura visión imaginativa, por medio de la irrealidad del sueño que la cubre. Siempre atento a toda vibración de sus bien desarrollados sentidos, el poeta pretende descubrir las relaciones escondidas que puedan existir ya, o sólo en potencia, en esta zona indeterminada entre él y su realidad. Muy consciente de su misión poética y desplegando un esteticismo simbolista en medio hostil, Julio Herrera y Reissig, por su capacidad de plasmar en forma exquisita sus visiones metafóricas, sumerge al lector en sus líricas impresiones, determinadas por estos constantes flujos y reflujos entre su propio yo y la realidad.

Allen W. Phillips, Universidad de Michigan. 